\title{
PARLAMENTARIZMO ISTORIJOS
} SKAITMENINIMAS:

PROBLEMOS IR SPRENDIMAI

\section{Vigintas Stancelis}

Vilniaus pedagoginio universiteto Istorijos fakultetas, lektorius Lecturer at Vilnius Pedagogical University Faculty of History T. Ševčenkos g. 31, LT-03111 Vilnius El.paštasVigintas.Stancelis@vpu.lt

Vilniaus universiteto Komunikacijos fakultetas, lektorius Lecturer at Vilnius University Faculty of Communication Saulètekio al. 9, LT-10222 Vilnius El.paštas vigintas.stancelis@kf.vu.lt

\section{Santrauka}

Straipsnis skirtas apžvelgti pasaulinę parlamentarizmo istorijos skaitmeninimo, duomenu baziu sudarymo ir publikavimo internete praktiką. Aptariami iššūkiai, su kuriais susiduriama skaitmeninant ir vèliau elektronineje erdveje panaudojant atstovaujamosios valdžios, ịstatymu leidybos istorijos dokumentus. Nagrinéjamos tokios problemos kaip duomenu formatu ir fiziniu laikmenu senejimas, büdu užtikrinti prieiga prie elektroniniu dokumentu ilgalaikeje perspektyvoje paieška. Analizuojami standartai, kuriais remiantis kuriamos skaitmeninès dokumentu kopijos ir sudaromi ju aprašai - metaduomenys, naudojami saugant, kataloguojant ir viešinant sukauptus fondus.

Svarstomi parlamentinés veiklos sričiu kèlimosi i elektronine erdvę, perejimo nuo popierinès prie elektroninès raštvedybos procesai ir ju galima itaka parlamentines istorijos dokumentavimui. Analizuojama pirmaujan- 
čių šaliu patirtis šiose srityse, žymiausi projektai, jų kryptys ir turinys, iškilesni skaitmeninimo centrai, ju naudojamos priemones ir darbu vykdymo metodika.

Reikšminiai žodžiai: skaitmeninimas; informacinès komunikacinès technologijos; e. parlamentas; parlamentarizmo istorija; duomenų bazès; metaduomenys; internetinis archyvas.

\section{Ivadas}

Straipsnio tikslas - išanalizuoti lyderiaujančių šalių (JAV, Jungtinės Karalystès, Vokietijos, Australijos, Nyderlandų, Belgijos) patirtị ir laimėjimus skaitmeninant senąji parlamentarizmo istorijos paveldą, taip pat elektroniniu būdu fiksuojant šiuolaikinès parlamentinès veiklos formas. Aptariami jau nusistovejję standartai ir besitęsianti naujų metodų ir priemonių paieška skaitmeninių dokumentų kūrimo, saugojimo ir sklaidos srityse. Dauguma kitų šalių, ịskaitant Lietuvą, žinoma, irgi turi savo ịdirbị ir laimèjimų, tačiau technologijų, standartų ir metodų srityje jos iš esmès seka minètų šalių patirtimi, todèl šiame straipsnyje nebus aptariamos.

Greta jau sukaupto patyrimo analizès, straipsniu siekiama bent jau iš dalies atsakyti ị naujai iškylančius klausimus. Vienas iš jų - būtinybè reikiamu laiku užfiksuoti ir išlaikyti elektroniniu formatu kuriamus ir platinamus parlamentinès veiklos produktus, nustatyti būdus, kaip jais būtų galima pasinaudoti ateityje, kai neišvengiamai pasikeis techninė ir programinè įranga. Taip pat svarbu, kad skaitmeniniu pavidalu išsaugota istorija taptų prieinama kuo didesnei auditorijai naudotojų - nuo profesionalaus tyrinètojo iki smalsaus moksleivio.

Archyvai ir parlamentinès bibliotekos seniai tarnauja kaip svarbių dokumentų saugyklos, atminties institucijos. Parlamentarizmo istorija kruopščiai archyvuojama visais galimais formatais - popieriuje, mikrofilmuose, kompiuterinėse laikmenose. Tačiau pasaulis keičiasi labai greitai, ir paveldo institucijų darbo metodai, jo organizavimas privalo neat- 
silikti nuo supančios tikrovès ritmo. Svarbu ne vien tik išsaugoti fizinius parlamentarizmo istorijos objektus, apsidraudžiant dar ir skaitmeninèmis jų kopijomis, bet ir sukurti priemonių sistemą, leidžiančią dabarties ir ateities virtualiems elektroniniams archyvams užtikrinti efektyvų prieinamumą prie sukaupto paveldo ${ }^{1}$. Prieš gerą dešimtmetị Jeremy'is Rifkinas, ekonomikos ir politikos mokslų specialistas, tiriantis mokslo ir technologijų ịtaką civilizacijos raidai, pasiūlè naują pavadinimą mūsų gyvenamai epochai - Prieinamumo amžius (Age of Access) ${ }^{2}$.

Siekiant tikro, visapusiško prieinamumo negalima apsiriboti pačiu siauriausiu skaitmeninimo proceso suvokimu - tiesiog nuskenuoti archyvines nuotraukas, perfotografuoti senus rankraščius, surašyti visa tai i CD, DVD plokšteles ir padèti ant lentynos - tegu sau guli, gal kada nors prisireiks. Teks atsakyti ị klausimus - kas bus šios medžiagos naudotojas ir kiek gausiai jų bus, ar jiems bus prieinami ir patogūs įrankiai, kuriais per atstumą „čiupinès“ dokumentą.

I elektroninę erdvę, palikdami praeityje popierių ir spaudos stakles, aktyviai keliasi ne tik žiniasklaida ar verslas, bet ir valdžios institucijos. Jungtinių Tautų ir Tarpparlamentinès sąungos bendro projekto Global Centre for Information and Communication Technologies in Parliament 2010 metų ataskaitoje teigiama, kad 85 proc. pasaulio parlamentų pavyko pagerinti savo veiklą, suaktyvinti bendravimą su piliečiais naudojant ivvairias interneto technologijas - nuo internetinių (angl. online) diskusijų, lankytojų balsavimų už vieną ar kitą pasiūlymą iki plenarinių posèdžių transliacijų ${ }^{3}$. Mums tai dabartis, skurdžiausioms šalims - ateitis, bet

\footnotetext{
${ }^{1}$ Scheeder, D. Digital Preservation and Parliamentary Libraries and Research Services. 26th Conference of IFLA Section for Libraries and Research Services for Parliaments. August 8, 2010. Prieiga per internetą: <http://www.riksdagen.se/upload/Dokument/biblioteket/Donna\%20Scheeder\%20Digital\%20preservation \%20in\%20Parliamentary $\% 20$ Libraries\%20and\%20Research\%20Services.pdf>.

${ }^{2}$ Rifkin, J. The Age of Access: The New Culture of Hypercapitalism Where All of Life Is a Paid-For Experience. Putnam Publishing Group, 2001, p. 320.

3 World e-Parliament report 2010, prepared by the Global Centre for Information and Communication Technologies in Parliament. United Nations, 2010, p. 8. Prieiga per internetą: $<$ http://www.ictparliament.org/wepr2010>.
} 
ateitị nuo praeities skiria vos akimirka, todèl jau laikas rengti priemones ir metodus, kad būtų išsaugota ir dabarties parlamentarizmo istorija.

Apžvelgiant užsienio tyrinètojų publikacijas šia tema tenka pastebèti, kad praktiškai nèra universalaus pobūdžio, viską apimančių darbų, paprastai juose nagrinejjamas kuris nors specifinis, autoriaus pasirinktas aspektas. Kaip labiausiai koncentruotą, ịvairiapusị leidinị vertètų išskirti 2002 m. Belgijos parlamente vykusio tarptautinio seminaro „Parlamentinès informacijos ir archyvų skaitmeninimas“ ataskaitą ${ }^{4}$. Šiame leidinyje publikuoti straipsniai susiję praktiškai su visų problemų spektru - nuo senųjų dokumentų skaitmeninių kopijų darymo iki bendravimo su rinkèjais elektroninèje erdvėje ịrankių, pristatoma tiek Vakarų (Prancūzijos, Ispanijos, Norvegijos), tiek Rytų Europos (Lenkijos, Vengrijos, Rusijos) šalių patirtis ir joms iškylančios problemos.

Daugelyje šalių parlamentarizmo istorijos kaupimas ir viešinimas, tarp jų - ir skaitmeninimas, yra patikètas parlamentinėms bibliotekoms. Keitho Cuninghame'o sudarytos Guidelines for Legislative Libraries ${ }^{5}$ nagrinejja praktiškai visus parlamentinès bibliotekos veiklos klausimus nuo fondų kaupimo iki bendravimo su parlamentarais, bet paveldo skaitmeninimas ir informacijos publikavimas elektroninėje erdvejje yra viena iš svarbiausių šio leidinio temų.

\section{Cui prodest? Kam tai naudinga?}

Ši frazè skambejjo jau Romos senate, bet galima ją pakartoti ir šiame straipsnyje. Peržiūrint Jungtinès Karalystės ir JAV Kongreso dokumentacijos skaitmeninimo nuostatus, dažnai ị akis krenta akcentuojama būtinybė prieš imantis bet kurio šio pobūdžio projekto prognozuoti jo būsimus rezultatus, praktinę naudą. Iš tiesų - kam mums to reikia ir ką mums tai duos?

${ }^{4}$ Digitisation Of Parliamentary Information And Archives. Prieiga per internetą: <www. senate.be/doc/misc/30-05-2002-eng.pdf>, p. 120.

${ }^{5}$ Cuninghame, K. Guidelines for Legislative Libraries. Mörlenbach, 2009, p. 136. 
Akivaizdu, kad pirmiausia galima paminèti tradicinį argumentą - darykime atsargines kopijas paveldo išsaugojimo tikslais, ypač jeigu tai seni, pažeidžiami dokumentai. Šią motyvaciją galima papildyti istorikų, archyvarų ir kitų parlamentarizmo tyrinètojų moksliniais interesais - taip suteiksime jiems geresnių galimybių pasiekti retus ar sunkiai prieinamus artefaktus. Tai pagrịsti ir svarbūs motyvai, tačiau būtų klaida ties jais sustoti.

Suskaitmeninti dokumentai galès atgal grịžti i politini gyvenimą, o ne tik dūlèti archyvų fonduose. Juose bus lengviau ieškoti informacijos, cituoti juos ne iš atminties, o visų mėgstamu klavišų deriniu CTRL+C, CTRL+V. Taigi skaitmeninimas pajègus išplèsti žinių bazę ne tik praeities tyrinètojams, bet ir patiems parlamentarams, jų padejejjams ir kitai politiškai aktyviai auditorijai.

Kol kas parlamentarizmo istorijos skaitmeninimas žengė ị priekị tarsi atbulas - žiūrèdamas ị praeitị, dešimtmečių ar net šimtmečių senumo dokumentus. Bet dabar daug parlamentinès veiklos dokumentų gimsta jau elektroniniu formatu ir, tapę įstatymais, iš karto virsta istorija. Jų tinkamas išsaugojimas ir pavertimas prieinamais - naujas skaitmeninimo veiklos horizontas, nes neaprašytas, užmirštas dokumentas istorijai neegzistuoja. Ne vien tik naujosios technologijos, bet ir didejantis bendradarbiavimas tarp skirtingų šalių parlamentų darys poveikị tam, kaip bus kuriami dokumentai ir organizuojamas ilgalaikis jų saugojimas.

Galų gale parlamentarizmas neįsivaizduojamas be kovos už rinkèjo simpatijas, bendravimo su juo. Technologijos kasmet atveria vis naujus tokio bendravimo kelius - nuo jau pabodusio elektroninio pašto iki tiesioginių internetinių konferencijų su 10-15 nuošalaus kaimelio rinkẻjų, kartu susėdusių prie kompiuterio vietinès bibliotekos viešosios interneto prieigos taške ${ }^{6}$. Ar šie laiškai ir pokalbiai turi mažesnę teisę ị išlikimą nei XVIII a. pamfletai ir peticijos?

${ }^{6}$ Viešųų interneto prieigos taškų (VIPT) atidarymai Šilutès rajone. 2008 m. spalio 7 d. Prieiga per internetą: <http://silute.kryptis.lt/main.php? parent $=269 \&$ module $=551 \&$ id=3422>. 


\section{Skaitmeninimo metodai ir standartai}

Nesiimkime nagrinèti konkrečių techninių ịrenginių - skenerių, skaitmeninių fotoaparatų specifikacijų ar jų naudojamos programinès įrangos. Žinoma, lyderiaujantys skaitmeninimo centrai dirba su unikalia, ypatingu galimybių technika, naudoja specialiai tam sukurtą programinę i̇rangą, bet ir tiksliausias jų parametrų ir galimybių perpasakojimas nepadarys jų mums labiau prieinamų. Vis delto likusiame pasaulyje skaitmeninimo galimybės yra palyginti vienodos, kai kada tai atliekama net biuro organizacinès technikos lygio techninėmis priemonèmis, o naudojamos programinès įrangos srityje dominuoja $A d o b e^{7}$ korporacijos programinis paketas, kuriuo galima apdoroti ir kūrybiškai interpretuoti praktiškai viską - retušuoti pažeistą nuotrauką, sumontuoti diktofono ar vaizdo kameros įrašą ar sudaryti interaktyvią, gausiai animuotą laiko juostą.

Nors juridiškai Nacionalinę skaitmeninès informacijos infrastruktūros ir išsaugojimo programą ${ }^{8}$ (National Digital Information Infrastructure and Preservation Program) JAV Kongresas patvirtino tik 2000 m. gruodžio mèn., Kongreso biblioteka jau ir anksčiau buvo sukaupusi didžiulị ìdirbị tiek parlamentarizmo istorijos, tiek bendro istorinio-kultūrinio paveldo skaitmeninimo srityje. Joje sukaupta patirtis yra viešai skelbiama ịvairių skaitmeninimo gairių pavidalu ir faktiškai tampa neoficialiu standartu daugumai kitų tokio pobūdžio centrų. Galima drąsiai teigti, kad ir Lietuvoje šie standartai yra gerai žinomi suinteresuotiems tyrinètojams bei specialistams ir pasitelkiami praktiniame darbe.

Bendradarbiaujant su daugeliu kitų valstybinių JAV institucijų, $2007 \mathrm{~m}$. buvo sudaryta skaitmeninimo standartų kūrimo programa Federal Agencies Digitization Guidelines Initiative (FADGI), kurioje išskirtos dvi darbo grupès - statiniams objektams (The Federal Agencies Still Image Digitization Working Group) ir audiovizualiniams įrašams (The Federal Agencies Audio-Visual Working Group) skaitmeninti'

${ }^{7}$ Adobe Creative Suite. Prieiga per internetą: <http://www.adobe.com>.

${ }^{8}$ Prieiga per internetą: $<$ http://www.digitalpreservation.gov $>$.

${ }_{9}$ Prieiga per internetą: $<$ http://www.digitizationguidelines.gov $>$. 
2010 m. rugpjūčio mèn. paskelbtose kultūrinio paveldo skaitmeninimo gairèse, skirtose rastrinio vaizdo objektams - rankraščiams, knygoms, nuotraukoms, j̧amžinti, smulkiai nagrinejjamos šios temos:

nejudrių vaizduojamųjų objektų skaitmeninis įamžinimas - ilgalaikiam saugojimui skirtų failų sukūrimas, vaizdo parametrai, skaitmeninimo priemonés ir aplinka;

spalvų valdymas, jų skiriamoji geba ir spalvinè temperatūra;

pateikiami darbo proceso pavyzdžiai - kaip apdoroti vaizdą, ji apkarpyti, išryškinti;

suskaitmenintų objektų aprašymas lydinčiais duomenimis - metaduomenimis (metadata), tam, kad ateityje galima būtų patogiai ir efektyviai rasti ir panaudoti sukauptą medžiagą;

aptariami failų formatai, rekomenduojami konkretūs sprendimai, kaip išsaugoti tam tikro tipo informaciją;

teikiamos rekomendacijos, kaip vadinti išsaugomus failus, taip pat patarimai dèl ilgalaikio saugojimo praktikos ${ }^{10}$.

Tiesą sakant, darbo fundamentalumas ir informacijos gausa gali nesunkiai paklaidinti mažiau patyrusị naudotoją. Glausčiau ir prieinamiau svarbiausi skaitmeninimo patarimai išdèstyti Nacionalinès archyvų ir irašų administracijos (National Archives and Records Administration) skaitmeninimo gairèse ${ }^{11}$. Jose surašytos paprastos ir praktiškos tiesos, kaip antai, kad tekstinius dokumentus tikslinga skenuoti ne mažiau kaip 200 dpi skiriamąja geba, bet rekomenduotina 300 dpi OCR ${ }^{12}$ tekstui atpažinti, naudoti didesnę skiriamąją gebą restauruotinoms nuotraukoms,

${ }^{10}$ Technical Guidelines for Digitizing Cultural Heritage Materials: Creation of Raster Image Master Files For the Following Originals - Manuscripts, Books, Graphic Illustrations, Artwork, Maps, Plans, Photographs, Aerial Photographs, and Objects and Artifacts. Prieiga per internetą: < http://www.digitizationguidelines.gov/guidelines/FADGI_Still_ImageTech_Guidelines_2010-08-24.pdf >.

${ }^{11}$ NARA Guidelines for Digitizing Archival Materials for Electronic Access. Prieiga per internetą: <http://www.archives.gov/preservation/technical/guidelines-1998.pdf>.

${ }^{12} \mathrm{OCR}$ - Optical Character Recognition, optinis teksto atpažinimas. Pasitelkus jị nuskaitytas dokumentas ịrašomas ne kaip paveikslèlis, o kaip tekstas. Ši procedūra dažniausiai naudojama tam, kad suskaitmenintą tekstą būtų galima redaguoti ir jame atlikti paiešką. 
vengti interpoliacijos. Nuskenuotus objektus išsaugoti ${ }^{*}$.tiff failų formatu, kuris leidžia užtikrinti geriausią atkūrimo kokybę.

Nors šis dokumentas publikuotas 1998 m. ir kai kurios jame aprašytos technologijos kiek senstelèjo, jo apibrěžta praktika veiksminga iki šiol. Štai ir kur kas vèliau - 2009-aisiais, Ilinojaus akademinių ir mokslinių biblioteku konsorciumo sudarytose gairèse ${ }^{13}$ remiamasi ta pačia suskaitmenintų vaizdų archyvavimo metodika, kad sukauptą turinị būtų galima patogiau pasiekti ir juo disponuoti. Rekomenduojama tam pačiam saugojimo vienetui naudoti 3 skirtingos kokybès ir panaudojimo būdo failus:

Master file - pirminis, didelès skiriamosios gebos, ${ }^{*}$.tiff formatu išsaugotas failas, tiksliausiai atkuriantis originalą. Jị vèliau galima panaudoti spaudai, retušavimui, kitų išvestinių failų kūrimui. Dèl nesuspaustų duomenų jis tiksliausiai išsaugo sukauptą informaciją, tačiau užima daug vietos kompiuterinėse laikmenose, reikalauja daug procesoriaus resursų juo manipuliuojant.

Access file - naudojimo failas, jis mažesnès apimties, skirtas peržiūrai, greitam spausdinimui, siuntimui elektroniniu paštu ar publikavimui internete. Jis kuriamas iš pirminio failo sumažinant jo skiriamąją gebą ir dydi, išsaugomas mažiau kokybišku *.jpeg formatu.

Thumbnail file - miniatūros failas, skirtas greitai peržiūrai, objekto atpažinimui, pvz., kataloguose, duomenų bazèse. Jam būdingi iš tiesų maži gabaritai ir minimali spalvinè skiriamoji geba, todèl rekomenduojamas ${ }^{*}$.gif failo formatas, turintis tik 256 spalvas. To pakanka, kad būtų galima nustatyti jame pavaizduotą asmeni, objektą, pastatą, o prireikus detalesnès peržiūros ar spausdinimo bus naudojamas didesnis *.jpeg failas.

Kokių problemų iškyla skaitmeninant garsini paveldą ir kokiomis priemonėmis ir metodais jos sprendžiamos, turbūt išsamiausią informaciją galima rasti $2005 \mathrm{~m}$. vasario mèn. pradèto bendro Indianos ir

${ }^{13}$ Guidelines For The Creation Of Digital Collections. Digitization Best Practices for Images and Text. Prieiga per internetą: < http://www.carli.illinois.edu/mem-prod/contentdm/ guidelines_for_digitization.pdf $>$. 
Harvardo universitetų projekto Sound Directions: Digital Preservation and Access for Global Audio Heritage dokumentacijoje ${ }^{14}$. Pagrindiniai šio projekto tikslai buvo: sukurti tinkamiausius standartus ir praktines rekomendacijas garso įrašų skaitmeninimui, abiejuose universitetuose vykdyti programas, kurios leistų tęsti tokio pobūdžio tyrimus, nedelsiant pradèti pavojingoje būklèje esančių unikalių ir kultūriškai vertingų îrašų konservaciją. Publikacijoje kruopščiai aprašoma naudota garso atkūrimo ir kompiuterinė įranga, analoginio signalo konvertavimo ị skaitmeninị procedūros, teikiami praktiniai patarimai. Kaip tinkamiausią garsinio paveldo išsaugojimui failų ìrašymo formatą tyrinètojai rekomenduoja nedaug kam girdètą ${ }^{\star} . b w f$ (Broadcast Wave Format). Iš pirmo žvilgsnio tai atrodytų kaip diskutuotinas sprendimas, bet pasikapsčius šio formato "genealogijoje“ paaiškejja, kad jis puikiai suderinamas su *.wav (Microsoft Wave), taigi nereikalauja specialaus grotuvo, o pranašesnis tuo, kad leidžia savyje išsaugoti įrašą aprašančius metaduomenis ${ }^{15}$.

\section{Sukauptos medžiagos ilgalaikio saugojimo užtikrinimas}

Kompiuterinèse laikmenose informacija vis dar yra labai pažeidžiama ir gali būti gana lengvai prarasta. Be to, techninès ir programinès irangos raida vyksta nuolat, ji greitai kinta ir sunku numatyti, kaip jau turimą elektroninę informaciją bus galima apdoroti po dvidešimt ar trisdešimt metų. Kaip užtikrinti, kad šiandien saugomus elektroninius dokumentus būtų galima perskaityti kompiuteriais ir programomis, kurie bus naudojami ateityje? Vienas iš sprendimo būdų - kopijuoti duomenis ì naujas laikmenas kuo dažniau, nes jos per keletą metų tampa nebenuskaitomos techniškai arba pasensta morališkai. Tačiau greta to kyla dar vienas sunkumas - sukaupta informacija galima pasinaudoti tik turint

${ }^{14}$ Casey, M., Gordon, B. Sound Directions. Best Practices For Audio Preservation, 2007. Prieiga per internetą: < http://www.dlib.indiana.edu/projects/sounddirections/papersPresent/sd_bp_07.pdf $>$.

${ }^{15}$ Specification of the Broadcast Wave Format (BWF), European Broadcasting Union, Geneva, 2011. Prieiga per internetą: $<$ http://tech.ebu.ch/docs/tech/tech3285.pdf $>$. 
atitinkamą programinę ịrangą, o jai vèl savo ruožtu reikalinga speciali techninè ịranga, kuri sensta ir genda lygiai taip pat greitai ${ }^{16}$.

Australijos Nacionalinio archyvo išleistose taisyklèse aprašoma ir nemažai kitų iššūkių. Skaitmeniniai ịrašai gali būti prarasti dèl gamtinių ir technogeninių veiksnių, pavyzdžiui, gaisro, potvynio, įrangos gedimo, virusų ar kompiuterinių ịsilaužèlių atakos. Elektroniniai dokumentai neretai apsaugomi slaptažodžiais, kodavimo algoritmais, kitomis duomenų apsaugos nuo nesankcionuoto panaudojimo priemonèmis, todèl netgi puikiai išsaugotas, visai nepažeistas ịrašas gali būti faktiškai neprieinamas. Saugomas dokumentas taip pat gali būti mažai panaudotinas dèl to, kad prastai identifikuotas, nepakankamai aprašytas, todèl jo negali rasti potencialūs naudotojas. Pavienis išlikęs failas be konteksto, be ji papildančių ir „aptarnaujančių“ failų-priedų gali padaryti jo turinị beveik nesuvokiamą ${ }^{17}$.

Technikos senėjimo, failų formatų kaitos problemai spręsti yra siūlomos dvi pagrindinès strategijos - migracija ir emuliacija. Migracijos šalininkai pasisako už dokumento konvertavimą ị naujesnius formatus, jeigu ankstesnysis jau paseno ir tapo nebenaudojamas, pavyzdžiui, senas Microsoft Word 2.0 failas išsaugomas Microsoft Word 2007 formatu ar paverčiamas *.pdf failu. Tačiau tai iškelia nemažai sunkumų - pirmiausia, tokios procedūros turètų periodiškai kartotis ir reikalautų didelių darbo sąnaudų. Duomenų formato pasikeitimas gali pažeisti dokumento vientisumą - jo pirminę išvaizdą, struktūrą, net turinị. Bègant laikui ir vykstant vis naujoms konversijoms galutinis dokumentas vis toltų nuo originalo $^{18}$. Be to, galimos ir šiuos dokumentus konvertuojančio personalo klaidos - visa elektroninè informacija yra lengvai keičiama, redaguoja-

${ }^{16}$ Bradley, K. Defining Digital Sustainability. Prieiga per internetą: $<$ http://www.ideals. illinois.edu/bitstream/handle/2142/3772/Bradley561.pdf?sequence=2>.

${ }^{17}$ Digital Preservation Policy. Preserving Archival Digital Records Transferred from Common wealth Agencies, July 2009. Prieiga per internetą: <http://www.naa.gov.au/images/ digital\%20preservation\%20policy_tcm16-41454.pdf $>$.

${ }^{18}$ van der Hoeven, J., Lohman, Bram, Verdegem, Remco. Emulation for Digital Preservation in Practice: The Results. The International Journal of Digital Curation. 2007, issue 2, vol. 2, p. 123-132. 
ma, todèl ar galime būti užtikrinti, kad ji nebus modifikuota ar dalis jos pašalinta kelių klavišų spustelèjimu?

Emuliacijos šalininkai siekia, kad elektroninių dokumentų panaudojamumas ateityje būtų užtikrintas išlaikant juos pirminiame, originaliame formate ir pasirūpinant, kad šių dokumentų tvarkymui skirta techninè ir programinè ịranga būtų visuomet prieinama. Kaip to pasiekti - negi šimtmečiais laikant parlamento rūsyje visus kadaise naudotus kompiuterius? Vietoj jų galima pasitelkti emuliatorius - programas, kurios dirba šiuolaikiniame kompiuteryje, tačiau imituoja jau nebeegzistuojančių ịrenginių darbą taip, kad senos programos ir jų duomenys jaučiasi "gimtoje“ aplinkoje. Emuliacijos pranašumas yra tas, kad ji leidžia perteikti originalią, pirminę skaitmeninio objekto išvaizdą, elgseną, valdymo būdus, o tai yra ne mažiau svarbu, kaip ir patys duomenys ${ }^{19}$. Be to, taupomos lèšos ir laikas - nereikia fiziškai ịsigyti ir prižiūrèti techninių ịrenginių, paveldo darbuotojams nereikia nuolat versti duomenų $\mathfrak{i}$ naujus formatus, perrašinèti ị naujas laikmenas.

Emuliacijos pritaikymo eksperimentai nuo 1999 m. atliekami Nyderlandų karališkojoje bibliotekoje, siekiant sukurti programinę aplinką, kuri leistų ateities kompiuteriuose naršyti mūsų laikais leistus interaktyvius CD, dirbti su internetinėmis publikacijomis. Siekiama užtikrinti, kad būsimas naudotojas galètų naudotis visomis svarbiausiomis išsaugoto elektroninio dokumento funkcijomis - paieška, spausdinimu, garso ir vaizdo atkūrimo priemonėmis ${ }^{20}$. Išsamiau apie emuliacijos pritaikymą parlamentarizmo istorijos skaitmeninimo praktikoje - skyrelyje apie parlamentinių interneto svetainių archyvavimą.

${ }^{19}$ Miura, G. Pushing The Boundaries Of Traditional Heritage Policy: Maintaining LongTerm Access To Multimedia Content By Introducing Emulation And Contextualization Instead Of Accepting Inevitable Loss. Prieiga per internetą: < http://archive.ifla.org/IV/ ifla72/papers/091-Miura-en.pdf>.

${ }^{20}$ Rothenburg, J. An Experimentin Using Emulation to Preserve Digital Publications. Amsterdam: National Library of the Netherlands, 2000, p. 74. Prieiga per internetą: $<\mathrm{http}: / /$ www.kb.nl/hrd/dd/dd_links_en_publicaties/nedlib/emulationpreservationreport.pdf $>$. 


\section{Prieigos prie sukauptų duomenų valdymas - duomenų bazès, metaduomenys}

Olandų archyvistas Bertas Looperis teigia, kad tam tikra prasme archyvistas ar kitas asmuo, disponuojantis tiek dabarties, tiek praeities dokumentais, yra monopolistas - tik jam prieinami tam tikri unikalūs, reikšmingi jo šalies ar net visos Europos, pasaulio istorijos raštai ir popieriai. Iki paplintant komunikacinèms technologijoms, jo monopolija lèmé fizinès prieigos prie dokumentų galimybes ir taisykles. Klasikiniai tokios prieigos užtikrinimo būdai buvo aprašai, katalogai, kitos labiau specifinès priemonès, kuriomis vadovaudavosi tyrinètojai, norèdami vẻlgi fiziškai pačiupinèti, pavartyti saugomą medžiagą. Dabar ši monopolija išplito ir ị skaitmeninę sferą. Atsiradus internetui, dominuojančiu darbo su dokumentu būdu tapo ne fizinis kontaktas su originalu, bet prisijungimas ir naršymas iš bet kurios pasaulio vietos pasiekiamoje duomenų bazèje, kur laikomos skaitmeninès kopijos. Iš esmès būsimos tyrinètojų kartos daugeliu atvejų dirbs nebe su archyvais ir kolekcijomis, bet tik su prieiga prie jų $\mathrm{u}^{21}$.

Kokia bebūtų ịvairi moksle, versle, kitose gyvenimo sferose naudojamų duomenų bazių tipologija, veikimo principai, sudètingumo laipsnis, joms visada keliami šie trys svarbiausi uždaviniai: duomenis saugoti, juos tvarkyti ir pateikti naudotojui, taip pat visus šiuos darbus atlikti maksimaliai veiksmingai. Iš paminètų trijų užduočių turbūt svarbiausia - duomenų pateikimas naudotojui. Nedaug vertas duomenų bazès dydis, duomenų gausa joje, jeigu neịmanoma išpešti jums reikalingos informacijos.

Kokių galimybių, o kartu ir problemų, iškyla skaitmeninimo ir duomenų bazių sąlyčio taške? Akivaizdu, kad siektina skaitmeninimo rezultatus saugoti, valdyti ir analizuoti pasitelkiant duomenų bazes. Tačiau

${ }^{21}$ European Centre for Parliamentary Research and Documentation. Digitisation of parliamentary information and archives. Brussels, 2002, p. 12-13. Prieiga per internetą: $<$ www. senate.be/doc/misc/30-05-2002-eng.pdf>. 
skaitmeninimo produktai daug kuo skiriasi nuo verslo informacijos, ir vienas tokių skirtumų - paprastai didelès failų apimtys. Tipinis komercinis įrašas, pavyzdžiui, prekès užsakymas, kažin ar užims kilobaitą pirkèjo vardas, pavardè, telefonas, užsakytos prekès pavadinimas, prekès vienetų skaičius, bendra apmokejjimo suma, pristatymo vieta, pristatymo terminas - visur trumpi tekstai ar skaičiai. Tačiau kokybiškai nuskenuotas dokumentas, o tuo labiau garso ar vaizdo įrašas užims megabaitus ar net gigabaitus. Neapgalvotai juos kimšdami į duomenų bazę didelès naudos nepatirsime - ji užims didžiulius diskų masyvus, reikalaus begalès kompiuterio resursų, veiks lètai, bus sudètinga daryti atsargines kopijas kitose laikmenose. Net esant sparčiam interneto ryšiui, jos naudotojams bus nepatogu naršyti - duomenys tinklu keliaus nepateisinamai ilgai.

Todèl svarbu tinkamai parengti duomenis dejjimui $\mathfrak{i}$ tokias duomenų bazes - parinkti nedaug vietos užimančius failų formatus nuotraukų peržiūrai, audiovizualinius failus konvertuoti ị srautinèms transliacijoms ${ }^{22}$ pritaikytus formatus. Ne mažiau svarbu skaitmeninimo produktus tinkamai aprašyti, kad duomenų bazejje būtų galima atlikti duomenų paiešką pagal kuo didesnị aktualių kriterijų kiekị - nuo faile vaizduojamo objekto iki skenerio ar kameros modelio, skaitmeninimą atlikusio darbuotojo ar paskutinès peržiūros datos.

Metaduomenys (pažodžiui - duomenys apie duomenis) yra struktūriškai apibrèžta informacija, kuri apibūdina, paaiškina informacinị išteklių, nurodo jo buvimo vietą arba kitokiu būdu palengvina jo suradimą, naudojimą arba valdymą ${ }^{23}$. Jie tradiciškai buvo naudojami bibliotekininkystejje ir tobulejjant technologijoms natūraliai išplito ì skaitmeninimo

\footnotetext{
${ }^{22}$ Srautinès transliacijos veiksmingos tuo, kad didelis garso ar vaizdo failas iš pradžių yra suspaudžiamas ir padalijamas ị mažus duomenų paketus, kurie vienas po kito siunčiami naudotojui internetu. Gavejjo kompiuteryje jie surenkami, išskleidžiami ir atkuriami grotuvu. Norint peržiūrèti valandas trunkantị ir gal net klaidingai pasirinktą filmą jo nereikia atsisiųsti viso - su šia technologija jị galima žiūrèti praktiškai realiu laiku.

${ }^{23}$ Varnienè, R., Daugiala, R. Virtuali skaitmeninio paveldo sistema - atminties institucijų sąveikos pagrindas. Prieiga per internetą: <http://www.lnb.lt/stotisFiles/uploadedAttachments/RVarnieneGDaugiala_Virtuali_skaitmeninio_paveldo_sistema2008101492515. pdf>.
} 
sferą, palengvindami duomenų katalogavimą bei paiešką. Ir pasaulinè, ir lietuviška skaitmeninimo praktika aktyviai naudoja metaduomenis sukauptos medžiagos organizavimui remdamasi DublinCore ${ }^{24}$ ir $X M L$ standartais $^{25}$.

Praktiškai kiekvienoje parlamentarizmo istoriją tiriančioje šalyje rasime internetu prieinamų duomenų bazių, kuriose publikuojami su parlamentarizmu, politinès sistemos raida susiję skaitmeniniai dokumentai. JAV Kongreso biblioteka ir šioje srityje neužleidžia vienos iš lyderių pozicijų. Teoriniame lygmenyje jos tyrejjai plètoja ir propaguoja darbo su metaduomenimis, aprašais, kitais duomenų valdymo įrankiais, standartus $^{26}$. Praktineje veikloje - rengia ir publikuoja parlamentarizmo istorijai ir dabarčiai skirtas duomenų bazes ${ }^{27}$. Jungtinejje Karalystejje paminètinos: centralizuota duomenų bazè Portcullis Archive Catalogue ${ }^{28}$, British history online parlamentarizmo sekcija ${ }^{29}$, Vokietijoje - Miuncheno skaitmeninimo centras (Münchener Digitalisierungs zentrum (MDZ), viena iš didžiausių ir aktyviai besivystančių skaitmeninių kolekcijų Vokietijoje, sukaupusi daugiau kaip 0,5 milijono dokumentų, prieinamų internetu ${ }^{30}$.

\section{Duomenų autentiškumo ir juridinès galios užtikrinimo problema}

Dokumentų skaitmeninimas tampa iššūkiu parlamentams persvarstyti savo tradicines procedūras. Šimtmečius popierius buvo ịrodymų nešejas, jame padètas parašas ar antspaudas liudijo dokumento tikrumą ir

\footnotetext{
${ }^{24}$ Prieiga per internetą: $<$ http://dublincore.org $>$.

${ }^{25}$ Prieiga per internetą: < http://www.w3.org/standards/xml/core>.

${ }^{26}$ Prieiga per internetą: < http://www.loc.gov/library/digitalstandards.html $>$.

${ }^{27}$ A Century of Lawmaking for a New Nation: U.S. Congressional Documents and Debates, 1774-1875; Documents from the Continental Congress and the Constitutional Convention, 1774-1789; THOMAS: Legislation in Current Congress. Prieiga per internetą: <http:// www.loc.gov/topics/content.php?subcat $=55>$.

${ }^{28}$ Prieiga per internetą: $<\mathrm{http}: / /$ www.portcullis.parliament.uk $>$.

${ }^{29}$ Prieiga per internetą: $<$ http://www.british-history.ac.uk/subject.aspx? subject $=6>$.

${ }^{30}$ Prieiga per internetą: $<$ http://www.digitale-sammlungen.de $>$.
} 
galią. Šiandien tenka susidurti su stebinančia dokumentų įvairove - nuo elementaraus tekstinio dokumento, statiškų diagramų iki garso ir vaizdo irašų ar interaktyvių aplinkų. Taip, visa informacija gali būti perkelta i skaitmeninį formatą, tačiau gresia problema, kad ne kiekvienas galès ja pasinaudoti be techninès paramos ${ }^{31}$.

Elektroninio, t. y. skaitmeninio parašo plitimas sukels nemažai kontraversiškų situacijų elektroninių dokumentų archyvavimo srityje, ir parlamentams verta pradèti tam ruoštis. Jis patogus naudoti versle, bendraujant internetu su valdžios institucijomis, juo galima patvirtinti dokumento autentiškumą ar apriboti nepageidaujamų asmenų prieigą prie neviešintinos informacijos. Elektroninis parašas - duomenys, kurie ịterpiami, prijungiami ar logiškai susiejami su kitais duomenimis jų autentiškumui patvirtinti ir (ar) pasirašančiam asmeniui identifikuoti. Dokumentų pasirašymui elektroniniu būdu naudojamas skaitmeninis sertifikatas.

Tačiau ši technologija paremta dviejų virtualių raktų - viešojo ir privataus - deriniu. Ir privatus raktas turi išlikti privatus - jo savininkas tuo pačiu parašu gali patvirtinti tiek viešą užklausą Seimui, tiek stambų finansinị sandèrị ar testamento sudarymą. Kaip tada būsimam archyvistui atverti užšifruotą dokumentą arba įsitikinti oficialaus laiško autentiškumu?

Net jeigu kokiu nors būdu privatus raktas būtų paviešintas, susiduriame su kita problema - šiuo metu elektroninis parašas paprastai yra susietas su kokiu nors fizinị pavidalą turinčiu elektroniniu ịtaisu, kuriame jis saugomas - specialia USB laikmena, asmens tapatybès kortelès mikroschema, mobiliojo telefono SIM kortele ${ }^{32}$. Net jeigu pririnktume dèžes šių prietaisų, kaip tai derès su internetinio archyvo koncepcija?

\footnotetext{
${ }^{31}$ Digitisation Of Parliamentary Information And Archives. Prieiga per internetą: <www. senate.be/doc/misc/30-05-2002-eng.pdf>,p. 6.

${ }^{32}$ Elektroninis parašas. Valstybinès mokesčių inspekcijos Elektroninio deklaravimo sistema. Prieiga per internetą: $<$ https://deklaravimas.vmi.lt/lt/Apie/Bendroji_informacija/Elektroninis_parasas.aspx $>$.
} 


\section{Organizaciniai sprendimai plečiant parlamentinès dokumentacijos skaitmeninimą}

Natūralu, kad senų, retų, lengvai pažeidžiamų, didelę istorinę vertę turinčių dokumentų skaitmeninimą verta patikèti profesionalams, turintiems šio darbo patirties ir specialią îrangą. Bet ar tai turi galioti kiekvienam kasdienio naudojimo dokumentui? Iki skaitmeninès revoliucijos parlamentas buvo pajègus pasirūpinti savimi - pakako raštininkų, vertejų, spaustuvininkų, archyvarų. Kodèl dabar turètų būti kitaip?

Šiuo klausimu vertinga naujausia Jungtinès Karalystės patirtis plečiant parlamentinès informacijos skaitmeninimą savo jègomis. $2008 \mathrm{~m}$. kovo mèn. abeji Jungtinès Karalystès Parlamento rūmai suderino bendrą dokumentą, pavadintą Digital Preservation Strategy ${ }^{33}$. Jame apibrèžiami su parlamentine veikla susietų informacinių resursų skaitmeninimo tikslai, priemonès ir apimtys. Šie resursai skirstomi i 3 kategorijas:

dokumentus, iš karto sukurtus skaitmeniniu formatu;

tradicinius dokumentus, kurie ị skaitmeninį formatą konvertuoti tam, kad būtų efektyviau panaudoti parlamentinio darbo veikloje, labiau prieinami ar ilgalaikio išsaugojimo tikslu;

atkurtus skaitmeninius dokumentus, kurie išliko tik analoginiu pavidalu - pvz., kompiuteriu parengti tekstai, kurie išliko tik spausdintine forma.

Skaitmeninis dokumentas traktuojamas kaip sudètinis objektas, kurị sudaro ne tik jo turinys - tekstas, nuotrauka, bet ir ji aprašantys metaduomenys. Techniškai metaduomenys gali būti ịdiegti i jais aprašomą objektą arba saugomi atskirai, svarbu, kad visuomet būtų išlaikomas nepertraukiamas ryšys tarp skaitmeniniu būdu sukurto ar suskaitmeninto dokumento ir ji apibūdinančių metaduomenų.

Lenteleje (35 p.) pateikiamas detalus veiksmų planas, kuriame pagal metus ir veiklos sritị suplanuoti būsimi darbai ir numatomi rezultatai,

${ }^{33}$ A Digital Preservation Policy For Parliament. Prieiga per internetą: < http://www.parliament.uk/documents/upload/digitalpreservationpolicy1.0.pdf>. 


\begin{tabular}{|c|c|c|c|c|}
\hline & 2008-2009 m. & 2009-2010 m. & $2010-2011 \mathrm{~m}$. & 2011-2012 m. \\
\hline 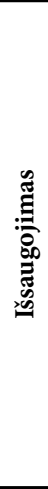 & $\begin{array}{l}\text { Technologijų } \\
\text { auditas: įvertinti, } \\
\text { kurios duomenų } \\
\text { saugojimo techno- } \\
\text { logijos jau pase- } \\
\text { nusios ir reikalau- } \\
\text { ja keitimo } \\
\text { Skaitmenine } \\
\text { „greitoji pagal- } \\
\text { ba“: } \\
\text { sukurti } 50 \text { TB } \\
\text { talpos saugyklą } \\
\text { duomenims, ku- } \\
\text { riems gresia gali- } \\
\text { mas praradimas }\end{array}$ & $\begin{array}{l}\text { Specifikacijų } \\
\text { kūrimas: } \\
\text { optimalių, naujau- } \\
\text { sių technologijų ir } \\
\text { ịrankių atranka } \\
\text { Paveldo išsaugo- } \\
\text { jimo užsakomo- } \\
\text { sios paslaugos: } \\
\text { identifikuoti, } \\
\text { kokie darbai turès } \\
\text { būti atliekami } \\
\text { pasitelkiant kitas } \\
\text { ịmones }\end{array}$ & $\begin{array}{l}\text { Skaitmeninè } \\
\text { saugykla: } \\
\text { virtualaus archy- } \\
\text { vo sukūrimas, } \\
\text { kur bus saugomi } \\
\text { dokumentai, } \\
\text { prieinami tiek } \\
\text { visuomenei, tiek } \\
\text { abejų parlamento } \\
\text { rūmų nariams }\end{array}$ & $\begin{array}{l}\text { Bandomieji pro- } \\
\text { jektai: } \\
\text { virtualaus archy- } \\
\text { vo užpildymas } \\
\text { turiniu, resursų, } \\
\text { kuriems gresia } \\
\text { išnykimo pavo- } \\
\text { jus, išsaugojimo } \\
\text { darbai, igūdžių ir } \\
\text { patirties kaupimas }\end{array}$ \\
\hline 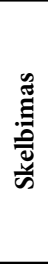 & & & $\begin{array}{l}\text { Priemonių ana- } \\
\text { lizè: } \\
\text { optimaliausių } \\
\text { būdų, kaip pa- } \\
\text { daryti saugyklą } \\
\text { prieinamą elektro- } \\
\text { ninejje aplinkoje, } \\
\text { paieška }\end{array}$ & \\
\hline 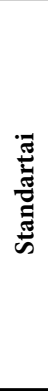 & $\begin{array}{l}\text { Poreikių identifi- } \\
\text { kavimas: } \\
\text { standartų, kurie } \\
\text { neatsiliktų nuo } \\
\text { pasaulinės in- } \\
\text { formacinių tech- } \\
\text { nologijų raidos, } \\
\text { paieška ir apibrè- } \\
\text { žimas. Duomenų } \\
\text { išsaugojimo ir mi- } \\
\text { gravimo politikos } \\
\text { suformavimas }\end{array}$ & $\begin{array}{l}\text { Atviri dokumen- } \\
\text { tavimo standar- } \\
\text { tai: } \\
\text { būdų išvengti } \\
\text { grèsmių, susijusių } \\
\text { su programinès } \\
\text { ịrangos pasenimu } \\
\text { ir kaita, paieška, } \\
\text { perdètų išlaidų } \\
\text { galimai duomenų } \\
\text { migracijoms pre- } \\
\text { vencija }\end{array}$ & & \\
\hline 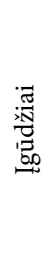 & & $\begin{array}{l}\text { Personalo ịverti- } \\
\text { nimas: } \\
\text { numatyti, kaip } \\
\text { efektyviausiai gali } \\
\text { būti panaudotas } \\
\text { personalas ir jų } \\
\text { turimi igūdžiai }\end{array}$ & $\begin{array}{l}\text { Mokymas: } \\
\text { suteikti žinias } \\
\text { ir igūdžius, rei- } \\
\text { kalingus darbui } \\
\text { su skaitmenine } \\
\text { saugykla ir ì ją } \\
\text { suplaukiančiu } \\
\text { duomenų srautu }\end{array}$ & $\begin{array}{l}\text { Laikino persona- } \\
\text { lo pasitelkimas: } \\
\text { per pirmus dvejus } \\
\text { metus užtikrinti } \\
\text { patikimą sau- } \\
\text { gyklos darbą ir } \\
\text { duomenų joje } \\
\text { kaupimą }\end{array}$ \\
\hline
\end{tabular}


kaip antai skaitmeninių saugyklų sukūrimas, personalo parengimas, viešos prieigos prie sukauptų resursų igyvendinimas ${ }^{34}$.

Po politinių sprendimų èjo techniniai. Tą patį $2008 \mathrm{~m}$. kovo mẻn. priimtos skaitmeninimo gairès ${ }^{35}$, skirtos ne mokslininkui-archyvistui, o pirminès grandies parlamentinių institucijų darbuotojui, atliekančiam kasdienị raštvedybos ar informacijos analizès darbą. Šie žmonès nedirba su retais parlamentarizmo istorijos paminklais, tačiau būtent jie gali kurti žymią skaitmeninimo produktų dalį.

Gairèse pažymima, kad su parlamentarizmo istorija susietų dokumentų skaitmeninių kopijų kūrimas gali būti naudingas daugeliu tiek mokslinių, tiek utilitarinių aspektų. Anksčiau tik popieriuje buvusi informacija tampa prieinama per internetą, ypač plačiajai auditorijai. Elektroniniame dokumente kur kas lengviau atlikti paiešką ir senuosius dokumentus tampa taip pat patogu naudoti, kaip ir sukurtus kompiuteriu. Kopijų kūrimas leidžia apsaugoti svarbius ar istoriškai vertingus dokumentus nuo fizinio nusidèvejjimo ir apgadinimo juos naudojant; padeda atlaisvinti erdvę, kurią parlamentarų biuruose užima analoginiai spaudiniai ir dokumentai.

Lygiai tokio pat racionalaus požiūrio siūloma laikytis nusprendžiant, ką skaitmeninti pirmiausia, ką vèliau, o ko galbūt atsisakyti. Siūloma iš pradžių ivvertinti, kokių dokumentų reikia naudotojams ir kaip jie juos gali pasiekti, kiek iš viso gali būti potencialių vieno ar kito dokumento naudotojų, ir kaip ilgai šis dokumentas gali būti reikalingas. Rekomenduojama atsižvelgti ir $\mathfrak{i}$ skaitmeninamo originalo būklę. Kadangi skaitmeninimas neišvengiamai susijęs su lèšų ir darbo laiko sąnaudomis, siūloma ịvertinti, ar jis gali būti atliktas savo pačių jègomis, ar reikès samdyti kitą darbuotoją, taip pat prognozuoti trukmę, kurią užims šio projekto igyvendinimas.

Kad atliktas darbas nepasimestų tarp kitų dokumentų, siūloma iš anksto apgalvoti, kaip galutinis produktas bus įtraukiamas į egzistuojančias parlamento sistemas, pvz., jo žiniatinklio centrą ${ }^{36}$, bibliotekas ir archyvus, parla-

\footnotetext{
${ }^{34}$ Prieiga per internetą: <http://www.parliament.uk/documents/upload/strategy-road-mapfinal-public.pdf $>$.

${ }^{35}$ Digitisation Guidelines, 2008, p. 8. Prieiga per internetą: <http://www.parliament.uk/ documents/upload/digitisation-guidelines.pdf $>$.

${ }^{36}$ Prieiga per internetą: $<$ http://parliamentlabs.wordpress.com $>$.
} 
mento tinklą. Neapeinami ir techninio pobūdžio klausimai: kokia skiriamoji geba reikalinga dokumento skenavimui, kiek vietos galutiniai produktai užims duomenų saugyklose, ar tekstai turi būti pritaikyti kompiuterinei paieškai, kokia bus nuotraukų ir kitų grafinių objektų aprašymo ir nuorodų sistema.

Skaitmeninimo produktai skirstomi i dvi kategorijas - kopijas darbiniam naudojimui ir ilgalaikiam saugojimui skirtas aukštos kokybės kopijas. Darbinès kopijos daromos standartiniais biuro skeneriais ar skaitmeniniais fotoaparatais ir skirtos ịrašyti ị tinklo diskus ar išsiuntinèti elektroniniu paštu darbo grupèms. Jos neturi išliekamosios vertès, todèl bus ištrinamos, kai tik taps nereikalingos. Atitinkamai joms keliami reikalavimai, kurių esmę sudaro bendro darbo patogumas, vietos diske ir elektroninio pašto děžutėse taupymas. Skenuotiems ir fotografuotiems objektams rekomenduojama 300 dpi skiriamoji geba, to pakanka tiek iprastiniam skaitymui, tiek automatizuotam teksto atpažinimui OCR priemonèmis, patariama skenuoti juodai baltu režimu, kad būtų dar labiau sumažinta failų apimtis, išsaugoti juos „ekonomiškais“*.jpeg ir *.pdf formatais.

Aukštos kokybės ilgalaikiam saugojimui skirtoms kopijoms keliami kiti reikalavimai - skenuoti ne mažesne nei 600 dpi skiriamąja geba, rezultatus išsaugoti * .tiff failų formatu, kuris, skirtingai nuo jpeg, galinčio atkurti tik 64 tūkst. atspalvių, leidžia išsaugoti praktiškai neribotą spalvų kieki (16,7 mln.). Istoriškai svarbių ir trapių dokumentų iš viso nerekomenduojama skenuoti standartiniais biuro ar industriniais skeneriais, o fotografuoti juos skaitmenine kamera ir prireikus kreiptis konsultacijos i parlamento archyvo specialistus ${ }^{37}$.

\section{Virtualios parodos ir kolekcijos}

Kaip jau apibrèžta įvade, skaitmeninių technologijų pritaikymas parlamentarizmo istorijai neturètų apsiriboti vien tik paveldo objektų išsaugojimu elektroniniu formatu, bet ir propaguoti tai, kas sukaupta, daryti ją prieinamą pačioms įvairiausioms auditorijoms.

${ }^{37}$ Digitisation Guidelines, 2008, p. 5. Prieiga per internetą: <http://www.parliament.uk/ documents/upload/digitisation-guidelines.pdf $>$. 
Šią istoriją sudaro ne tik posėdžių stenogramos, protokolai, priimtų i̊statymų originalai ar nuorašai. Politinis gyvenimas vyksta tam tikroje realioje architektūrinejje erdvejje - parlamento pastate (pastatuose). Dažnai šie pastatai turi turtingą istoriją, yra vertingi architektūriškai, juose sukauptos istorijos paminklų ar meno objektų kolekcijos. Skaitmeninės technologijos tai, kas anksčiau buvo prieinama tik išrinktiesiems, politiniam elitui, gali padaryti prieinamą kiekvienam, nesvarbu, kur jis gyventų. Dar geriau kiekvienas gali rinktis individualų, patogiausią ekskursijos laiką ir tempą.

Suprantama, kad Jungtinès Karalystès Parlamentas su jo daugelio šimtmečiu istorija ir turtingiausiu istoriniu bagažu puikiai pasinaudoja tokia galimybe skleisti informaciją apie save, pritraukti susidomejjusius. Parlamento svetainëje tam yra skirta viena iš reikšmingiausių rubrikų ${ }^{38}$ (žr. 1 iliustraciją). Greta informavimo apie tiesioginio apsilankymo parlamente galimybes, taisykles ir terminus, renginių ir parodų anonsus, yra parengta nemažai virtualių ekskursijų. Susipažinę su nesudètingais valdymo įrankiais, jūs, kaip tipiniame kompiuteriniame žaidime, galètumète pasivaikščioti po daugelị patalpų, iš arčiau pasižiūrèti ị žymių politikų statulas ar senovinius baldus. Jei kam nepakaktų tik gražių paveikslèlių, daugelyje šių virtualių erdvių galètų rasti internetinių nuorodų ị straipsnius apie šių salių istoriją, jose saugomas istorines vertybes, architektus, kurie jas rekonstravo. Kai kurių komitetų salèse galima peržiūrèti vieną kitą vaizdo įrašą apie visai neseniai čia vykusius debatus.

Audiovizualinèje parlamento svetainès dalyje Watch and Listen $^{39}$ sukaupti videoturai po parlamentą, kur jo istoriją pristato jau nebe kompiuterinis pasivaikščiojimų simuliatorius, bet gyvas gidas. Jeigu esate per daug užimtas, kad galètumète nuolat žiūrèti ị kompiuterio ekraną, galite rinktis tik igarsintas paskaitas apie parlamento istoriją ar šiandienos aktualijas.

Žinoma, tokio pobūdžio pasivaikščiojimai ar paskaitų klausymas daugiau skirti pirmiems apsilankymams, tai auditorijai, kuri dar tik susidaro pirmus įspūdžius apie parlamento veiklą. Aktyviai įsitraukusiam $\mathfrak{i}$

\footnotetext{
${ }^{38}$ Prieiga per internetą: < http://www.parliament.uk/visiting >.

${ }^{39}$ Prieiga per internetą: $<$ http://www.parliament.uk/about/podcasts/>.
} 


\section{1 iliustracija}

You are here: Parliament home page > Visiting > Online tours > Interactive map of Parliament > Committee Rooms

\begin{tabular}{l}
\hline Online tours \\
\hline $\begin{array}{l}\text { Interactive map of } \\
\text { Parliament }\end{array}$ \\
\hline Commons Chamber \\
\hline Lords Chamber \\
\hline Clock Tower \\
\hline Westminster Hall \\
\hline Central Lobby \\
\hline Committee Rooms \\
\hline Lords Visitor Route \\
\hline Lords Library \\
\hline House of Commons \\
Library \\
\hline St Stephen's Hall and \\
\hline Chapel Cloister \\
\hline Victoria Tower \\
\hline Basement \\
\hline Portcullis House \\
\hline Video and audio \\
\hline transcripts \\
\hline
\end{tabular}

\section{Committee Rooms}

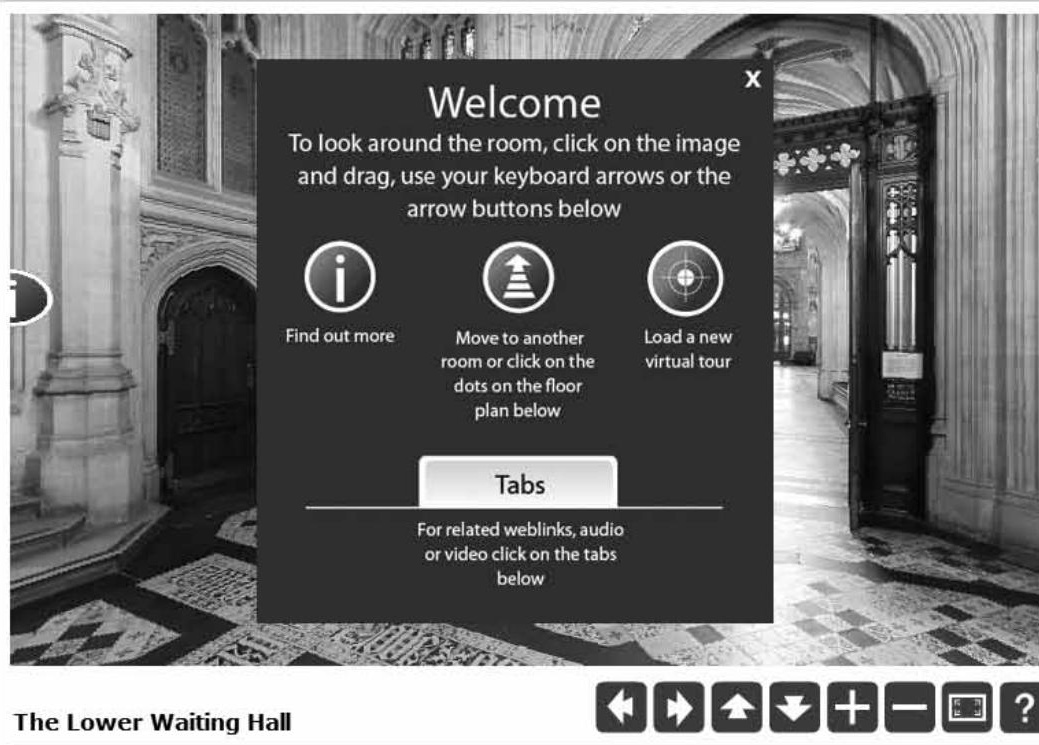

politinị gyvenimą turbūt aktualesnè Parliament TV rubrika, kur galima tiesiogiai stebėti Bendruomenių ar Lordų rūmų posėdžius arba susirasti rūpimo posėdžio vaizdo įrašą elektroniniame archyve $e^{40}$.

Tiek JAV Kongreso Atstovų rūmų ${ }^{41}$, tiek Senato ${ }^{42}$ ar net jų atskirų padalinių ${ }^{43}$ internetinèse svetainèse galima rasti nemažai medžiagos apie šių parlamentinių institucijų praeitị, paprastai ji sutelkta skyreliuose Art \& History. Publikuojami istoriniai straipsniai apie žymias asmenybes, pačios institucijos istoriją, statistiniai duomenys apie par-

\footnotetext{
${ }^{40}$ Prieiga per internetą: $<$ http://www.parliamentlive.tv $>$.

${ }^{41}$ Prieiga per internetą: <http://www.senate.gov>.

${ }^{42}$ Prieiga per internetą: $<$ http://www.house.gov $>$.

${ }^{43}$ Prieiga per internetą: $<$ http://clerk.house.gov $>$.
} 
lamentinę veiklą tam tikru laikotarpiu. Tačiau paminètose svetainèse dominuoja tradicinio pobūdžio, statiškas informacijos pateikimas. Gyviau atrodo specialiai bendravimui su plačiąja publika skirtas portalas Visit the Capitol ${ }^{44}$. Nors pradinis puslapis pasitinka lankytoją santūriu, pakankamai konservatyviu dizainu, jame yra virtualių parodų skyrelis, kuriame gauna progą pasirodyti daugelis moderniųjų skaitmeninimo ir vizualizacijos technologijų. Interaktyvioje laiko juostoje galima naršyti Kongreso ir visos šalies istoriją. Pasirinkus tam tikrą istorinị periodą ir spustelejus ant sudominusio portreto, nuotraukos, dokumento, galima perskaityti jo aprašą, apie naujesnius laikus išklausyti garso įrašą ar peržiūrèti trumpą reportažą. Jeigu pasirinktume seną rankraštinị dokumentą, ji galètume ne tik peržiūrèti iš arčiau, bet ir gauti jo transkripciją spausdintiniu tekstu.

\section{Sakytinès parlamentarizmo istorijos ir vaizdo ịrašų skaitmeninimas}

2004 m. buvo pradèta JAV Kongreso Atstovų rūmų sakytinès istorijos programa ${ }^{45}$ (žr. 2 iliustraciją), kurios tikslas padaryti šią paveldo rūši prieinamą tiek Kongreso nariams, personalui, tyrinėtojams, tiek ir plačiajai auditorijai. Joje siekiama įrašyti pačių îvairiausių darbuotojų, kaip antai Kongreso narių padejejejų, komitetų darbuotojų, pagalbinio personalo, net šeimų narių prisiminimus. Taip pat ịrašomi pokalbiai ir su tam tikrais parlamentarais. Irašytuose interviu rasime detaliai atkurtus kelių dešimtmečių senumo ịstatymų leidybos procesus ir procedūras, asmenybių likimus ir politinius anekdotus, kitus Kongreso vidaus gyvenimo aspektus.

Sukaupti čia dirbusių žmonių prisiminimai teikia galimybę šiandienos Kongreso personalui susipažinti su praktika, galiojusia šioje institucijoje praeityje, jie gauna tam tikros informacijos, galinčios būti aktualia ir dabarties sprendimams. Kuriant ši resursą tarp daugelio tikslų buvo ir

\footnotetext{
${ }^{44}$ Prieiga per internetą: $<$ http://www.visitthecapitol.gov $>$.

${ }^{45}$ Prieiga per internetą: $<$ http://oralhistory.clerk.house.gov $>$.
} 


\section{2 iliustracija}

\section{Oral Allistony

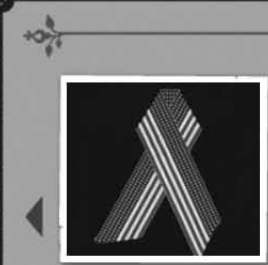

SEPTEMBER 11, 2001

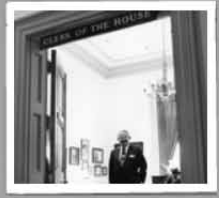

DONNALD K. ANDERSON 1960-1995

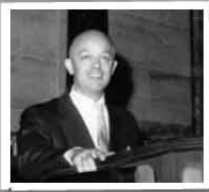

JOE BARTLETT 1941-1944; 1945-1979

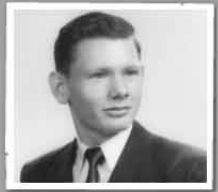

BILL GOODWIN 1953-1955

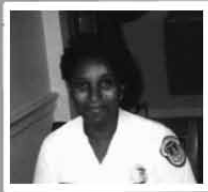

ARVA MARIE JOHNSON 1974-2007

siekis stiprinti susidomėjimą JAV Kongreso Atstovų rūmų istorija, aktyvinti jos studijas.

Sakytinès istorijos interviu įrašomi naudojant garso ir/arba vaizdo ịrangą. Projekto vykdytojai greta paties įrašo taip pat daro tekstines pokalbio transkripcijas, sutrumpintus pokalbio reziumè. Sukaupti garso ir vaizdo įrašai publikuojami Center for Legislative Archives at the National Archives and Records Administration (NARA), Kongreso bibliotekoje, taip pat projekto svetainèje.

Kaip šio projekto, taip ir daugelio kitų garso ir vaizdo įrašų sudarinètojai praktiniame darbe vadovaujasi Sakytinès istorijos asociacijos ${ }^{46}$ dar 1989 m. išleistomis ir periodiškai (2000, 2009 m.) atnaujintomis gairèmis. Aptarkime svarbiausius jų akcentus.

Prieš garso įrašo darymą rekomenduotina suplanuoti išankstinị susitikimą su interviu respondentu, kuriame būtų pristatyti interviu organizavimo tikslai, apibūdintos būsimame garso ịraše aptariamos temos ir

${ }^{46}$ Prieiga per internetą: $<$ http://www.oralhistory.org $>$. 
klausimai, suplanuotas pats garso įrašymo procesas. Šio susitikimo metu asmeniui, iš kurio imamas interviu, turètų būti išaiškinta, ko iš jo tikimasi, nurodytos jo teisès redaguoti interviu turini, riboti tam tikros medžiagos skelbimą, užtikrinti, kad ịrašai išliktų neskelbtini ir konfidencialūs, kol jų autorius neduos galutinio sutikimo juos skelbti.

Interviu turètų būti imamas tylioje patalpoje su minimaliais foniniais triukšmais, vengiama kitų išorinių trikdžių. Interviu imantis asmuo pokalbio įrašą turètų pradèti nuo įvadinès informacijos - paminèti respondento vardą ir pavardę, nurodyti, kada įrašomas pokalbis, kur jis vyksta, kokia pagrindinè jo tema, taip padėdamas jam susikoncentruoti, prisiminti numatytus pokalbio tikslus. Abi šalys turètų iš anksto susitarti dèl pokalbio trukmès.

Nors tam tikra improvizacija, tiriamieji klausimai interviu metu gali būti naudingi ir produktyvūs, vis dèlto pagrindinè pokalbio tema turètų laikytis iš anksto numatytos vagos. İrašą darantys asmenys turi gerbti pasisakančiojo teisę vengti diskutuoti tam tikromis temomis arba kai kuriais atvejais net išlikti anonimiškais. Interviu pabaigoje rekomenduotina gauti respondento raštišką sutikimą perduoti įrašytą medžiagą archyviniam saugojimui ${ }^{47}$.

\section{Parlamentinių interneto svetainių archyvavimas}

JAV Kongreso skelbiamai informacijai internete archyvuoti buvo isteigtas projektas MINERVA (santrumpa iš Mapping the INternet Electronic Resources Virtual Archive) ${ }^{48}$. Šiuo metu šiame virtualiai prieinamame archyve saugomos 107-ojo (2001-2002 m.) ir 108-ojo (20032004 m.) JAV Kongreso narių internetinių svetainių kopijos, iš viso 1162 saugojimo vienetai. Ankstyvesnèms kolekcijoms jos surinktos atlikus vienkartinị sinchronizuotą visų svetainių kopijavimą, pvz., visų 107-ojo

${ }^{47}$ Prieiga per internetą: <http://www.oralhistory.org/wp-content/uploads/2009/10/OHA principles_standards.pdf $>$.

${ }^{48}$ Prieiga per internetą: < http://lcweb2.loc.gov/diglib/lcwa/html/lcwa-home.html $>$. 
Kongreso narių svetainès išsaugotos $2002 \mathrm{~m}$. gruodžio $12 \mathrm{~d} .{ }^{49}$ Tame pačiame projekte sukauptos 2000-2008 m. JAV vykusių prezidento, Kongreso narių, gubernatorių rinkimų svetainès, iš viso apie 11120 saugomų svetainių kopijų. I kolekciją ịeina ne tik pačių rinkimų dalyvių, bet ir susijusių organizacijų - remiančių partijų, rinkimų štabų, šalininkų ar rinkimus stebinčių grupių svetainès. Vèlyvesnèse kolekcijose jau galima matyti nebe vienetinị laiko pjūvị, bet daug tos pačios svetainès versijų, atsekti, kaip ji kito laike, pvz., 2007-2008 m. intervale saugomos 86 skirtingų datų http://www.barackobama.com svetainès kopijos.

Kiekviena kolekcija organizuota duomenų bazès principu, ją galima naršyti pagal 3 kategorijas - temą, pavardę ir organizacijos pavadinimą. Duomenų bazès naudotojas iš karto mato svarbiausią statistiką, pavyzdžiui, 2008 m. rinkimų kolekcijoje galima rinktis iš 1806 temų, 1298 pavardžių ir 2189 pavadinimų $u^{50}$. Taip pat galima naudotis paieška - rūpimo dalyko ieškoti tuo metu naršomoje duomenų bazejje arba iš karto visose kolekcijoje.

Smulkiau aptarkime kolekcijos kaupimo principus ir panaudotas priemones. Duomenys kaupiami tiesiogiai bendradarbiaujant su svetainių savininkais - kandidatais, partijomis, organizacijomis, gavus jų sutikimą. Vykdant projektą siekiama surinkti visą programinị kodą, iliustracijas, svetainejje publikuotus dokumentus ir kitus failus tam, kad būtų atkurta kuo tikslesnè originali svetainè. Išsaugomi visi techniniai metaduomenys, kaip antai naršymo data ir laikas, atsako trukmè. Data ypač svarbi vèliau nustatant skirtingas svetainès versijas. Surinkti duomenys saugomi tiksliai tokie, kokie buvo gauti, HTML kodas ir failų formatai nèra modifikuojami ${ }^{51}$.

Kita proceso stadija - pateikti surinktą medžiagą naudotojui ir, pageidautina, kuo tiksliau atkuriant to laiko išvaizdą ir pojūčius. 20012002 m. svetainès buvo kuriamos visai kitoms interneto naršyklių pro-

\footnotetext{
${ }^{49}$ Prieiga per internetą: $<$ http://lcweb2.loc.gov/diglib/lcwa/html/107th/107th-overview.html $>$. ${ }^{50}$ Prieiga per internetą: <http://1cweb2.10c.gov/diglib/lcwa/0008browse?list $=$ names\&start $=\mathrm{A}>$.

${ }^{51}$ Prieiga per internetą: <http://www.loc.gov/webarchiving/technical.html $>$.
} 
gramoms ir versijoms negu naudojame dabar ir tuo labiau naudosime po 10 metų. Šiai problemai spręsti MINERVA projekto vykdytojai remiasi anksčiau aprašytu emuliacijos metodu, senųjų svetainių atkūrimui naudodami specialų programinị ịrankị Wayback. Iš esmès tai yra perdirbtas ir patobulintas The Internet Archive Wayback Machine variantas. Dar 1996 m. visuomeninė pelno nesiekianti organizacija Internet Archive ${ }^{52}$ pradejjo kaupti, archyvuoti svetainių kopijas. Senų svetainių atkūrimo besikeičiančia programine ịranga problemai kasmet tampant vis aktualesnei, buvo parengtas įrankis, galintis pakankamai tiksliai atkurti tuometinị archyvuotų kopijų vaizdą - iliustracijoje (žr. 3 iliustraciją) galime palyginti 1996 m. (kairejje) ir 2011 m. (dešinejje) Jungtinès Karalystès ir JAV Atstovų rūmų interneto svetainių vaizdą.

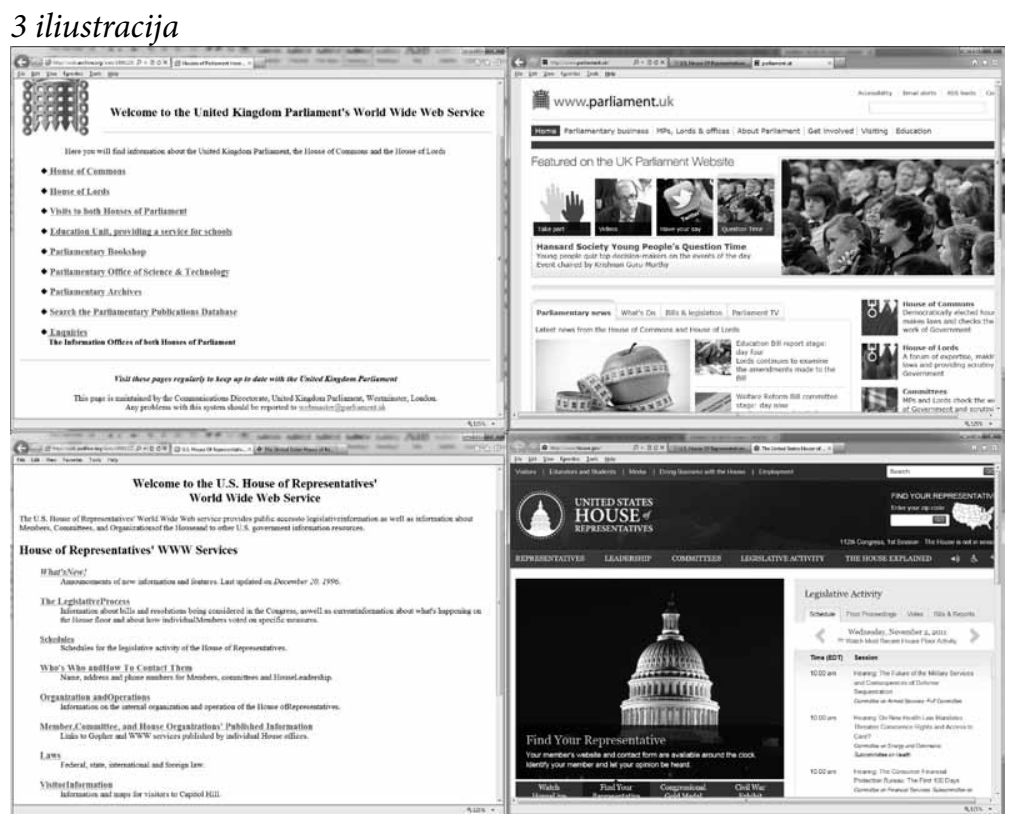

${ }^{52}$ Prieiga per internetą: $<$ http://www.archive.org $>$. 


\section{Išvados}

Intensyvi skaitmeninimo techninès įrangos pažanga sudaro prielaidas plèsti jos taikymą fiksuojant ir tiriant parlamentarizmo istorijos paminklus, o plintanti parlamentinès veiklos, tarpparlamentinio bendradarbiavimo, bendravimo su rinkejjais ir interesų grupėmis formų ivairovė kelia naujus uždavinius skaitmeninant jau sukauptą paveldą ir fiksuojant kuriamą šiuo metu.

Galima konstatuoti, kad praktiškai jau nusistovejjo pasauliniu mastu bendri statinės vaizdo medžiagos (tekstinių dokumentų, nuotraukų, piešinių) skenavimo ir fotografavimo standartai ir metodika, bet audiovizualinio paveldo fiksavimo srityje vis dar vyksta pakankamai aktyvi optimalių sprendimų paieška. Tęsiamas skaitmeninị turinị aprašančių metaduomenų sistemos tobulinimas ir plètra, bet iš esmès jis vyksta remiantis jau gerai žinomais Dublin Core ir XML standartais.

Tuo pat metu išlieka aktualios ir tradiciškai skaitmeninimui būdingos problemos - kompiuterinèse laikmenose sukauptos informacijos ilgalaikio saugojimo, turinio autentiškumo garantavimo, kiek įmanoma tikslesnio atkūrimo iš skaitmeninių kopijų uždaviniai.

Parlamentinès veiklos plètra ì elektroninę erdvę ir pasaulinị tinklą, perejjimas nuo popierinès prie elektroninès raštvedybos iškelia nemažai naujų iššūkių parlamentinès veiklos produktų ir paminklų išsaugojimo srityje. Skaitmeniniu pavidalu sukurti dokumentai, internetinių svetainių puslapių medžiaga, virtualių transliacijų ir vaizdo konferencijų ịrašai tampa parlamentarizmo istorijos tyrimo objektais, todèl reikia pasirūpinti tinkamu jų išsaugojimu.

Pastebètina tendencija, kad dideja skaitmenini parlamentarizmo istorijos turinị kuriančių žmonių grupe - greta profesionalių skaitmenintojų nemažai skaitmeninių produktų kuria asmenys, tiesiogiai dirbantys parlamentinejje sferoje, - nuo pačių parlamentarų iki juos aptarnaujančio techninio personalo.

Tebelieka aktuali efektyvios prieigos prie suskaitmeninto parlamen- 
tarizmo paveldo problema tiek mokslininkui profesionalui, siekiančiam iš internetu pasiekiamų duomenų bazių gauti kokybiškas kopijas, tiek ir istorija besidominčiai visuomenès daliai, moksleiviams, studentijai, kuriems būtų ịdomūs apibendrinti, kūrybiškai interpretuoti skaitmenimo produktai - vizualizacijos, virtualios ekskursijos, internetinès šviečiamosios garso ir vaizdo transliacijos.

\section{DIGITIZATION OF PARLIAMENTARY HISTORY: PROBLEMS AND SOLUTIONS}

\section{Vigintas STANCELIS}

\section{Summary}

Keywords: digital preservation; information and communication technologies; e-parliament; parliamentary history; databases; metadata; Internet archive.

Standards and methodology for static visual material digitization (textual documents, photographs and drawings) become worldwide unified more than decade ago, but search for optimal solutions how to capture and preserve an audiovisual heritage is still undergoing. Research how to improve collected data description and handling continues as well, but main principles are based on already well-known Dublin Core and XML standards framework. At the same time, remains unsolved one of oldest problems of digitization - ensure that the digitized information, stored in computerized form will be available after long-term storage. It means not only physical integrity of kept data, but guaranteeing the authenticity of the content, providing appropriate hardware, software and skills to manipulate them in future.

Continuous progress of computer hardware and digitization software allows Iteikta $2011 \mathrm{~m}$. spalio $11 \mathrm{~d}$. expand work on parliamentary history research and conservation into new areas. Spreading of parliamentary activity over Internet and electronic mass media, interparliamentary cooperation, contemporary ways of communication with voters and interest groups brings good possibilities and intriguing challenges at same time.

Parliamentary work expansion in the virtual space and a global network, the transition from paper based to electronic documents requires creating methods and means timely and accurate preserve this form of heritage. Digitally created documents, Web pages of parliaments, online broadcasts and video-conferencing records becomes an object of parliamentary history and needs not only be to preserved but delivered to concerned audiences, like archivists, historians, teachers and school students. 